Article

\title{
Life Cycle Assessment of an Innovative Technology against Late Frosts in Vineyard
}

\author{
Fabiana Frota de Albuquerque Landi ${ }^{1}\left(\mathbb{D}\right.$, Alessia Di Giuseppe ${ }^{1} \mathbb{D}$, Alberto Maria Gambelli ${ }^{2}$, \\ Alberto Palliotti ${ }^{3}$, Andrea Nicolini ${ }^{1,2, *(D)}$, Anna Laura Pisello 1,2 and Federico Rossi ${ }^{1,2}$ (D) \\ 1 CIRIAF, Università degli Studi di Perugia, 06125 Perugia, Italy; landi@crbnet.it (F.F.d.A.L.); \\ alessia.digiuseppe@crbnet.it (A.D.G.); anna.pisello@unipg.it (A.L.P.); federico.rossi@unipg.it (F.R.) \\ 2 Dipartimento di Ingegneria, Università degli Studi di Perugia, 06125 Perugia, Italy; \\ albertomaria.gambelli@unipg.it \\ 3 Dipartimento di Scienze Agrarie, Alimentari e Ambientali, Università degli Studi di Perugia, \\ 06121 Perugia, Italy; alberto.palliotti@unipg.it \\ * Correspondence: andrea.nicolini@unipg.it
}

check for updates

Citation: Frota de Albuquerque Landi, F.; Di Giuseppe, A.; Gambelli, A.M.; Palliotti, A.; Nicolini, A.; Pisello, A.L.; Rossi, F. Life Cycle Assessment of an Innovative Technology against Late Frosts in Vineyard. Sustainability 2021, 13, 5562. https://doi.org/ $10.3390 /$ su13105562

Academic Editors:

Elena Cristina Rada

and Vincenzo Torretta

Received: 12 March 2021

Accepted: 12 May 2021

Published: 17 May 2021

Publisher's Note: MDPI stays neutral with regard to jurisdictional claims in published maps and institutional affiliations.

Copyright: (c) 2021 by the authors. Licensee MDPI, Basel, Switzerland. This article is an open access article distributed under the terms and conditions of the Creative Commons Attribution (CC BY) license (https:/ / creativecommons.org/licenses/by/ $4.0 /)$.

\begin{abstract}
Wine production is a key sector for the Italian economy, representing 13 billion euros per year. The proportion of the market raises concerns about improving the production technology at low cost, safe practices, and low environmental impacts. The recurrent life cycle assessment performed does not report on the impacts of frost protection. This study presents the potential environmental impact of a novel late frost protection technique for vineyards that is currently under development. It consists of an organic coating made of sugar and straw to prevent vine damage due to frosts in vineyards in the coldest hours of late winter and early spring. From previous research at the University of Perugia (Italy), the technique has proven to be an effective protection method for vine shoots. Currently, the yields are protected by highly energy-demanding methods. For this study, we simulated two different scenarios of frosting protection so we could point out possible hotspots for the field application of the novel method and compare it to a technique usually employed in central Italy. Under the Centrum voor Milieukunde Leiden (CML) method, the cotton candy technique is estimated at $316 \mathrm{~kg} \mathrm{CO}_{2}$ equivalent emissions for hectare. Employing the organic sugar-coating means avoiding $69,375 \mathrm{~kg}$ of $\mathrm{CO}_{2}$ eq. compared to the traditional technique of oak wood-burning into the vineyard. Preliminary cost analysis demonstrated the economic viability of implementing the organic coating.
\end{abstract}

Keywords: life cycle assessment; wine sector in Italy; thermal insulation system; frosting prevention; frosting protection

\section{Introduction}

In 2019, the worldwide production of grapes reached 77 million tons and 263 million hectoliters of wine. Italy is the second country in grape production after China, with about 8 million tons of grapes, both wine and table grapes, and leads the wine production sector with 47.5 million hectoliters of wine [1,2]. The production of wine grapes by region in Italy is shown in Figure 1, with Puglia, Veneto, and Emilia-Romagna leading. 


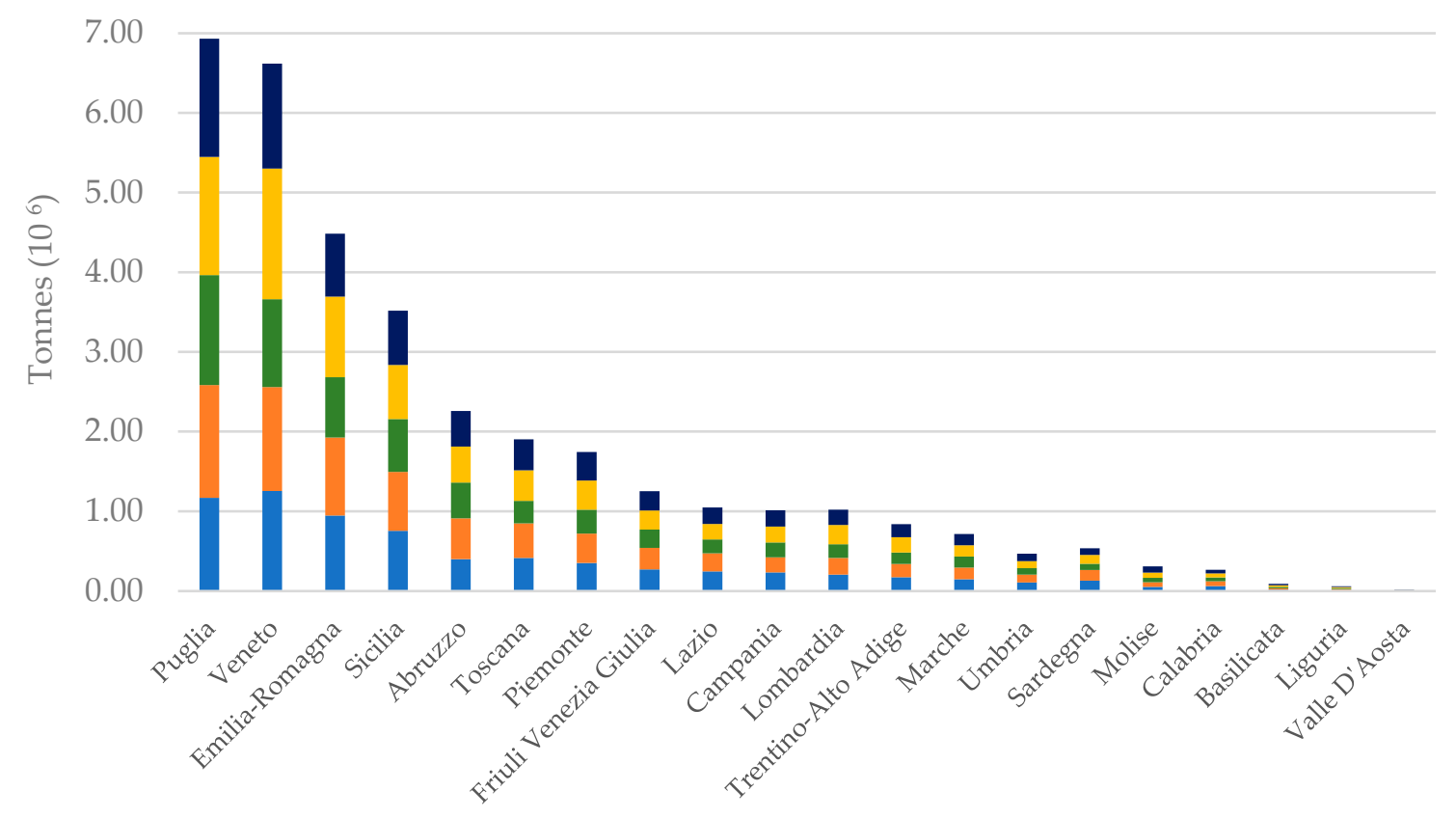

Figure 1. Wine grapes production per Italian regions [1,2].

As in most Mediterranean countries, viticulture is essential for the Italian economy, with a total turnover of 13 billion euros for the wine sector [3] and around 600 million euros for table grapes [4].

Agriculture and climate change are strictly connected in food systems, i.e., from farming to waste disposal. Food systems are responsible for around $19-29 \%$ of the total greenhouse gas (GHG) emissions from human activities [5], expecting to double by 2030 [6]. Farming activities are responsible for almost half of the emissions from the food sector [7]. At the same time, the increased frequency and intensity of extreme natural events (i.e., heat waves, heavy precipitation), as a consequence of climate change, affect food crops production and quality.

The climate change impact in the viticulture sector is explained when considering that budburst, flowering, and veraison are all temperature-dependent phenological stages [8]. Some authors have assessed that the warmer temperatures are associated with an earlier occurrence of grapevine phenology. Moreover, under future scenarios in Europe [9]: budburst occurred 8-11 days earlier in France in the Duchêne et al. [10] investigation. Leolini et al. [11] assessed that budburst occurred 7-11 days earlier in Spain and flowering shifts from 16-18 days earlier in Italy. Veraison occurred 21-35 days earlier in France, as stated by Cuccia et al. [12].

The grape composition and wine quality are significantly influenced by the anticipated grapevine stages, resulting in negative modifications of acid composition, anthocyanins accumulation, sugar content, ethanol content, and flavor composition [13-15]. In particular, an anticipated budburst may expose young shoots to an increased risk of late frosts, which are one of the major threats to vineyards. However, the results in the literature are contrasting. Leolini et al. [11] stated that the late frost risk tends to increase in central Europe (e.g., Germany) and to decrease in Western Europe (e.g., France, Spain, and United Kingdom). On the other hand, Molitor et al. [16] estimated fewer late frosts risks in central Europe (e.g., Luxembourg), with event occurrence earlier than at the budburst grapevine stages. Orlandini et al. [17] showed a higher probability of late frost episodes in Tuscany, Italy. In this regard, central Italy presented five important episodes that canceled the grape production in 1991, 1997, 2003, 2016, and 2017, i.e., one event every 5-6 years. Intense spring frost events were also observed in the Po and bottom valleys of grape cultivation zones.

In this framework, an innovative protection method against late frosts in vineyards has been developed at CIRIAF (Interuniversity Center on Pollution and Environment 
Mauro Felli) at the University of Perugia and tested at lab scale with encouraging results. It consists of an insulation coating made of cotton candy and straw [18,19].

In previous experimental works, such a strategy was found to be effective both in the absence and in the presence of wind [18]. In the latter case, the addition of straw improved the insulating layer performance. Further in situ research will assess the implementation of the novel method at diverse elevations, site exposition, wind, and vegetation cover since those factors are determinants for lower or higher event incidence [20,21]. Overall, the air temperature and the target temperature to prevent damages are the most important parameters to be considered $[20,22,23]$.

Late frosts occur at the end of the winter and the beginning of the spring when the young shoots (budburst stage) are vulnerable to low temperatures [20]. Late frosts can be divided into convective, radiative, and advective frosts [20,22-25].

Convection frosts are associated with airflow in different temperatures $[20,24,25]$. During the daytime, excluding direct solar radiation, air temperature decreases with height. During the night, in the absence of solar radiation, the higher density cold air moves along with the landscape profiles.

The most important Italian agricultural areas are mainly affected by the radiative late frosts, sometimes combined with advective frosts [24,26]. Radiative frosts usually occur on clear and calm nights with daily temperatures higher than $0{ }^{\circ} \mathrm{C}$ [22]. They are characterized by a temperature inversion through a radiant exchange which leads to the loss of the energy accumulated during the day, resulting in soil and crops cooling [27]. The thermal inversion represents the first cause of late frosts.

The advective frosts occur when the air temperature falls below $0{ }^{\circ} \mathrm{C}$ also during the day, besides windy and cloudy conditions caused by cold air blows from higher latitudes [26]. More in-depth, streams of cold and dry air from the north, with wind velocity equal to or higher than $30-50 \mathrm{~km} / \mathrm{h}$, usually cause those frosts. Temperature decreases very quickly and may generate the so-called black frost, whose name is referred to the low content of water vapor and the consequent lack of hoarfrost (in the latter, the term usually adopted is "white frost") [22].

Frost protection is commonly divided into active or direct methods and passive or indirect methods [20,22,23,27], with cost as an important decision factor [23]. Active methods are distinguished in shielding, dynamic, and thermal techniques [24] that must be enabled prior to and during the frost event, while passive techniques are associated with early site decisions such as location, type of products, and agricultural practices [21,22].

The combustion technique is classified as a shielding method [24] and may employ different types of fuels such as wood, paraffin, and oil. Burners and stoves are commonly used to produce heat near vegetation for the whole duration of the frost, reducing or avoiding damages. The air shielding power enhances when the humidity in the air increases near the ground due to the artificial fog, preventing energy losses from the soil [26].

The dynamic method relies on the use of mechanical ventilation to prevent thermal inversion by air mixing. The scope is to mix cold air near the soil with the warmer air from the upper layers, pushing it down to the crop's [24], providing a uniform temperature in the first $10-12 \mathrm{~m}$.

The first anti-frost fan in Italy was installed at the Arnaldo Caprai winery in Umbria (central Italy), financed by local contributions (Agroclim Technology Project). It consists of a retractable propeller, which can be hidden when not operative. The use of fans allows a temperature increase of about $5-6^{\circ} \mathrm{C}$ in the surrounding 4 hectares of the vineyard [25]. However, fans are considerably higher in costs when compared to other techniques, being sometimes prohibitive for many factories. According to E. B. Poling [22], the initial cost of equipment is $\$ 28,000$ (4 hectares). Other sources report costs of $£ 30,000$ to $£ 35,000$ [25,28-30]. Moreover, this equipment would be used only a few days per year, and the long-term exposition to weathering requires frequent maintenance.

For last, the thermal devices include heaters and sprinklers. The first one provides heat to warm up the air at ground and crop level, while the second one exploits the heat 
during a phase change from water to ice [24]. The frost-free irrigation method is divided into three solutions: over-foliage, soil, and micro-irrigation [27].

The over-foliage solution consists of evenly distributing water upon the vegetation, with medium water flow rates that vary according to the site [20] and level of protection required [23]. Irrigation must be carried out for the whole duration of the frost. The water phase transition produces a little heat, avoiding the temperature of buds below the ice formation inside the cells. The frost-free irrigation is effective, but it is rarely used in Umbria, according to the experience of the authors due to the elevated implementation costs and the high consumption of water.

Soil irrigation allows the prevention of possible damages which may occur to branches for the heaviness due to ice. Similar to the previous method, it is based on heat release associated with the phase transition of water but considering that it does not directly occur in correspondence of buds, it needs significantly higher water flow rates. Among the under-plant sprinklers, micro-sprinklers are the most efficient ones [24].

Finally, micro-irrigation is carried out immediately below foliage and requires more than half of flow rates than over-foliage irrigation; however, it is applicable only for a limited number of cultivations. The adoption of irrigation would require thousands of meters of pipes and hundreds of dispensers, as well as pumps and tanks. Besides, the risk of ice formation inside pipes would require elevated maintenance costs. Therefore, even if associated costs are significantly variable in function of the specific application, they are considered higher than those techniques previously described. R. G. Evans [20] estimated an initial cost (in the Washington area, the year 2000) for overvine and undervine sprinklers of about $\$ 2200$ to 3000 per hectare.

On the other hand, the passive or indirect defense involves preventive measures carried out before frost events, mainly based on crop selection for the timing of phenological development to counteract frost damage. The passive defense includes ecological and biological techniques [26].

In this context, the innovative insulating coating to prevent late frost damages in vineyards, already tested at lab-scale, takes place to obtain a sustainable and cost-effective technical solution using the traditional technique, like burn oak wood into the vineyard, employed in Umbria, as a benchmark.

Consumers are increasingly sensitive to the sustainability of food production, and particularly in the wine sector, this concept is being linked to superior quality, thus increasing the product added value [31]. The environmental performance of all wine life cycle stages have been largely investigated and reported in the Literature: as stated in Bartocci et al. [32], the carbon footprint of an aged vineyard, obtained by Grechetto and Sagrantino Umbrian grapes varieties varies between 1.94 and $2.54 \mathrm{~kg} \mathrm{CO}_{2} / \mathrm{L}$, and the most impactful life cycle stage is the viticulture, i.e., the nutrient management process $(25-32 \%)$, while the wine aging contributes $3.30-3.80 \%$ to the environmental impact. Moreover, in Neto et al. [33], the viticulture practices (e.g., soil preparation, grapes harvesting) show the largest contribution (more than 50\%) to the life cycle environmental impact of Portuguese wine. In contrast, the production of the glass bottle seems to be the biggest environmental impact stage, as seen in a study carried out in Tuscany [34] with a carbon footprint ranging from 0.7 to $1.3 \mathrm{~kg} \mathrm{CO}_{2}$ eq. for a $0.75 \mathrm{~L}$ bottle. In summary, despite varying results depending on the criteria, such as type of wine, geography, and production methods, these studies show the concerns regarding the environmental impact of this industry. No Life Cycle Assessment (LCA) study regarding the frost protection management in vineyards was found in Literature, except in Barry [35].

In this framework, using the Umbria wine production region in central Italy as a study case, the specific goals of the current work were to: (1) estimate the environmental impact of the novel frost protection in comparison to a traditional method used in the geography selected, (2) to point out the critical hotspots to improve the technique, and (3) perform a cost analysis of the proposed technique compared to the traditional practice in the geography. 


\section{Materials and Methods}

The potential environmental impact of the organic coating technique was calculated through the life cycle assessment methodology for supporting decision-making and investigating hotspots in products or activities [36]. The method, often used for industrial processes, is standardized by the ISO series $14,000[37,38]$ and should be structured according to the steps presented in this section. The framework is composed of a goal and scope definition, inventory analysis, life cycle impact assessment, and interpretation [39] performed along with the study.

\subsection{Goal and Scope Definition}

This study aims to evaluate the potential environmental impact of the application of a novel technique (Figure 2a,b) under development at the University of Perugia to prevent late frost in vineyards. All experiments that currently evaluated the technique's feasibility consisted of small-scale laboratory tests with climate conditions simulated into a climatic chamber. It was possible to accurately regulate the temperature, relative humidity, and wind velocity inside the controlled environment. Besides, an electrified wire simulated the real plant to establish well the ingoing and outgoing thermal flow.

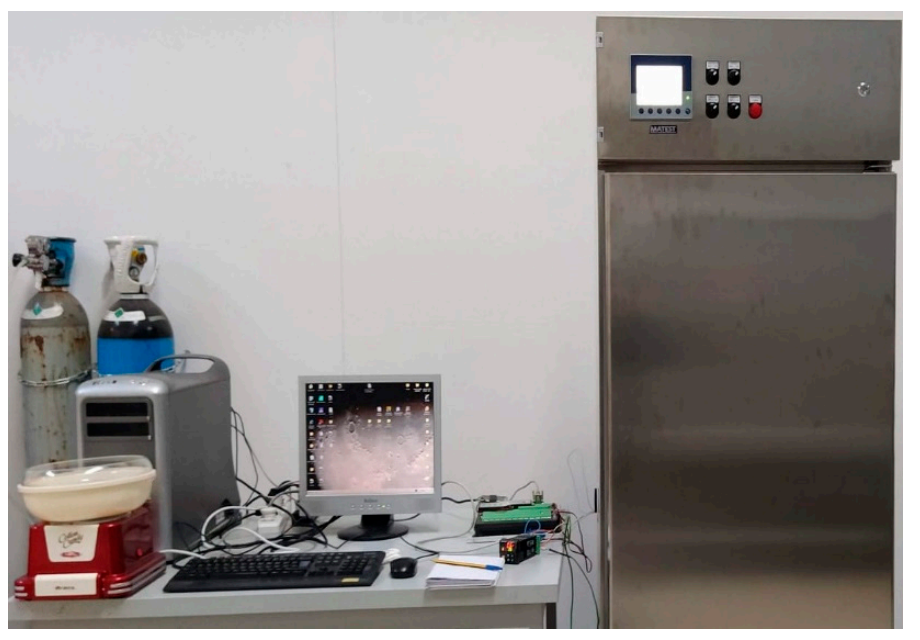

(a)

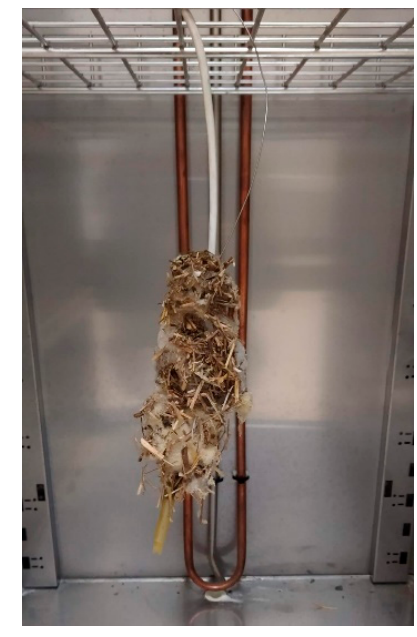

(b)

Figure 2. Images of the experimental apparatus (from left to right: a cotton candy machine, a data logger, a Hall effect sensor, a Proportional-Integral-Derivative (PID) controller, and a climatic chamber) (a), and the organic coating prototype (b) Reprinted from ref. [18].

We performed a cradle-to-gate of one hypothetical operation and compared it to the most standard practice as the benchmark. In Umbria, the geography of interest in this study, the most adopted technique consists in heat production via combustion of woods or other materials. This method represents the oldest active defense techniques, employing artificial fog by burning organic materials at the crop level, and it is defined as a benchmark method for comparison with the innovative technique analyzed in the present work.

\subsection{Functional Unit}

The functional unit in this study that determines the performance of the system [36] corresponds to the inputs and outputs to protect one hectare of vineyard with the organic coating.

\subsection{Boundaries}

The boundaries of this study were set according to Figure 3. The materials and processes needed to apply the organic anti-frosting technique were defined by the involvement of experts and the experiments on a lab scale. We limited the study to the inputs and 
outputs to produce and apply the anti-frosting system, excluding the vine grape production. The benchmark process used for comparison is the traditional wood-burning (oak) that is often employed in the Umbria region in central Italy [40]. Data from the Italian National Institute of Statistics (Istat) [41] for the Region Capital (Perugia) reported the incidence (from 2002 to 2016) of 19 days with snow, 17 cold days, and 25 cold nights. For the traditional method, wood production, field setting, and burning processes and materials were considered.

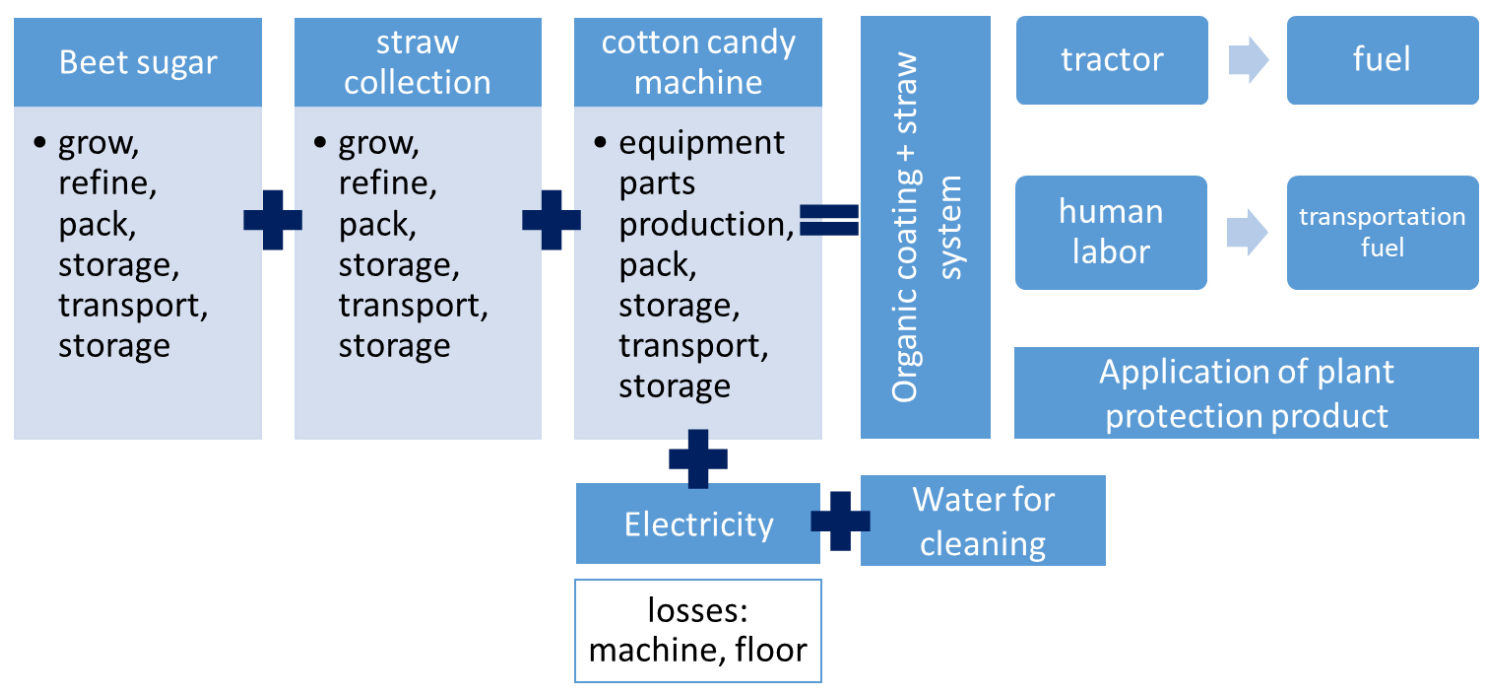

Figure 3. Boundaries scheme for the organic coating system.

\subsection{System Description}

The organic coating assembly model considers a stainless-steel heated bowl that spins and produces sugar filaments. In contact with air temperature, those filament turns into solid.

To improve frost resistance, according to previous research $[18,19]$, the coating was added to dry straw fiber at $20 \%$ of filament mass during the rotational movement. When it comes to the field operation, the sugar processing machine would be placed in a circulating agriculture tractor between the vineyards. We consider one hectare of vineyard corresponding to 25 beds, which is the typical density in Umbrian vineyards. The operation should take around $4.6 \mathrm{~h}$, and considering a machine with $3000 \mathrm{~W}$, the energy consumption equals $68.8 \mathrm{kWh}$.

The benchmark system is the traditional technique using 120 spots of fire capable of protecting one hectare of a vineyard for $8 \mathrm{~h}$. The calculations considered that $5000 \mathrm{~kg}$ of wood could produce $315 \mathrm{~W} / \mathrm{m}^{2}$ [20]. The oak calorific value is $18.125 \mathrm{MJ} / \mathrm{kg}$ [42]. Since most of this heat dissipates to the air, we cannot adopt an equivalence of heat produced by the fire or the heat maintained by the novel technique.

\subsection{Life Cycle Inventory (LCI)}

The inputs for the organic coating calculations were considered as follows in Table 1. The cotton candy machine's lifespan was estimated to be 5 years. Table 2 presents the inputs for the traditional wood-burning system. The inputs were obtained from the ecoinvent database [43]. 
Table 1. Inputs for producing the organic coating.

\begin{tabular}{|c|c|c|}
\hline \multicolumn{3}{|l|}{ Sugar Organic Coating and Straw } \\
\hline \multicolumn{3}{|l|}{ Materials/assemblies } \\
\hline Sugar, from sugar beet $\{$ GLO $\}$ | market for I Alloc Def, $U$ & 0.5 & ton \\
\hline Straw $\{$ GLO $\}$ I market for I Alloc Def, U & 0.1 & ton \\
\hline Polypropylene, granulate $\{\mathrm{GLO}\}$ | market for | Alloc Def, $\mathrm{U}$ & 1.5 & $\mathrm{~kg}$ \\
\hline Tap water $\{$ Europe without Switzerland $\}$ I market for I Alloc Def, U & 1 & $\mathrm{~kg}$ \\
\hline \multicolumn{3}{|l|}{ Processes } \\
\hline Application of plant protection product, by field sprayer $\{$ RoW $\} \mid$ processing $\mid$ Alloc Def, $U$ & 1 & ha \\
\hline Transport, tractor and trailer, agricultural $\{\mathrm{GLO}\} \mid$ market for I Alloc Def, $\mathrm{U}$ & 1.5 & $\mathrm{tkm}$ \\
\hline Transport, passenger car $\{$ RER $\}$ I market for | Alloc Def, U & 40 & $\mathrm{~km}$ \\
\hline Stretch blow moulding $\{$ GLO $\}$ | market for | Alloc Def, U & 1.5 & $\mathrm{~kg}$ \\
\hline \multicolumn{3}{|l|}{ Cotton Candy Machine (5 Years Lifespan) } \\
\hline \multicolumn{3}{|l|}{ Materials/assemblies } \\
\hline Steel, low-alloyed $\{\mathrm{GLO}\}$ | market for | Alloc Def, U & 13 & $\mathrm{~kg}$ \\
\hline Cable, three-conductor cable $\{G L O\}$ I market for I Alloc Def, U & 5 & $\mathrm{~m}$ \\
\hline $\begin{array}{l}\text { Corrugated board boxes, technology mix, prod. mix, } 16.6 \% \text { primary fibre, } 83.4 \% \text { recycled fibre EU- } 25 \mathrm{~S} \\
\text { Processes }\end{array}$ & 3 & $\mathrm{~kg}$ \\
\hline Transport, freight, light commercial vehicle $\{\mathrm{GLO}\}$ | market for $\mid$ Alloc Def, $U$ & $0.015 \times 1500$ & $\mathrm{tkm}$ \\
\hline Electricity, low voltage $\{\mathrm{IT}\} \mid$ | market for | Alloc Def, $U$ & 68.75 & $\mathrm{kWh}$ \\
\hline
\end{tabular}

Table 2. Inputs for the traditional wood-burning technique.

\begin{tabular}{lc}
\hline Materials/Assemblies & \\
\hline Wood chips, wet, measured as dry mass \{RoW\} | hardwood forestry, oak, sustainable forest & 5000 \\
management | Alloc Def, U & 10 \\
Polypropylene, granulate \{GLO\} | market for | Alloc Def, S & $\mathrm{kg}$ \\
Processes & $\mathrm{kg}$ \\
\hline Transport, freight, lorry, unspecified \{GLO\} | market for | Alloc Def, U & 650 \\
Transport, passenger car \{RER\} | market for | Alloc Def, U & 40 \\
Transport, tractor and trailer, agricultural \{GLO\} | market for | Alloc Def, S & 10 \\
Extrusion, plastic film \{GLO\} | market for | Alloc Def, U & $\mathrm{km}$ \\
Wood burning & 10 \\
\hline
\end{tabular}

\subsection{Data Acquisition}

The quantities input data were estimated according to the laboratory tests, while the processes scaling was estimated according to the experience of the expert. The ecoinvent V3 database [43] loaded using SimaPro 8.4.0.0 [44] was used for the input and output calculations. The wood-burning process was modeled according to "treatment of waste wood, untreated, open burning" from ecoinvent version 3.7.1 [45].

\subsection{Life Cycle Assessment (LCA) Model}

The impact assessment was done in two steps using the CML baseline, which is often employed for simplified studies [46]. First, we analyzed the novel technique system to identify where most of the emissions are produced. Later, a comparison with the traditional practice was made.

The selected method covers 10 impact indicators as midpoint oriented. The CML-IA, developed by the University of Leiden (Netherlands), includes the use of fossil resources (including energy), greenhouse gas emissions and ozone depletion, photochemical oxidation, fresh water and marine aquatic ecotoxicities, eutrophication, acidifications, and human and terrestrial toxicity $[36,46]$. 


\section{Results}

\subsection{Organic Coating System Impact Assessment}

The global warming indicator is presented in Figure 4 . The total emissions attributed to the protection of one hectare of the vineyard are $316 \mathrm{~kg} \mathrm{CO}_{2}$ eq. From the cotton candy and straw system, $86 \%$ of the $\mathrm{CO}_{2}$ eq comes from the market of sugar beet, $70.6 \%$ being from its production. The application process is responsible for almost $5 \%$ of the emissions, transportation of laborers corresponds to about $4.5 \%$, the straw about $3 \%$, and the rest is considered the packaging. Regarding the cotton candy machine, the greenhouse gas emissions are distributed at $32 \%$ for the machine transportation, $31.8 \%$ for the electricity usage, almost $19 \%$ from its steel material, and around $16 \%$ for the cabling system.

\begin{tabular}{|c|c|}
\hline Impact category & Global warming (GWP100a) \\
\hline Unit & $\mathrm{kgCO} 2 \mathrm{eq}$ \\
\hline Market sugar beet & 248.29 \\
\hline Market straw & 8.62 \\
\hline Market Polypropylene & 3.08 \\
\hline Tap water & 0.00 \\
\hline Application (sprayer) & 12.60 \\
\hline Tractor & 0.57 \\
\hline Transport, passenger car & 12.87 \\
\hline Stretch blow moulding & 2.82 \\
\hline Machine Steel & 4.78 \\
\hline Machine packaging & 0.69 \\
\hline Machine Transport & 8.79 \\
\hline Machine Electricity & 8.69 \\
\hline Machine Cabling & 4.45 \\
\hline
\end{tabular}

Figure 4. Global warming indicator for 100 years' timeframe, in $\mathrm{kg} \mathrm{CO}_{2}$ eq.

The other indicators show that most of the impacts are concentrated in the market for sugar and cabling for the cotton candy machine (Figure 5). For the last one, more specifically in abiotic depletion, marine aquatic and freshwater eco-toxicity, and human toxicity, due to the metallic components such as copper. The straw is important in terrestrial eco-toxicity, as it is responsible for almost all this impact due to the straw rye production and $28 \%$ of the freshwater aquatic eco-toxicity emissions.

\subsection{Organic Coating System Comparison with Traditional Wood-Burning Technique}

The comparison of the novel organic coating shows that fossil fuel depletion, global warming, ozone depletion, photochemical oxidation, human toxicity, freshwater, eutrophication, and acidification are higher for the wood-burning traditional technique (Figure 6). For instance, the $\mathrm{CO}_{2}$ eq emissions (Global warming indicator) are 220 times higher for the wood-burning practice than the organic coating system. The human toxicity (in $\mathrm{kg} 1,4-\mathrm{DB}$ eq) is 20 times higher for the wood-burning system and almost 68 times higher for the photochemical oxidation indicator (in $\mathrm{kg} \mathrm{C}_{2} \mathrm{H}_{4}$ eq). As seen previously, the terrestrial eco-toxicity and marine aquatic indicators are affected by the straw production component. 


\begin{tabular}{|c|c|c|c|c|c|}
\hline Impact category & Abiotic depletion & $\begin{array}{l}\text { Abiotic depletion } \\
\text { (fossil fuels) }\end{array}$ & $\begin{array}{l}\text { Photochemical } \\
\text { oxidation }\end{array}$ & Acidification & Eutrophication \\
\hline Unit & kg Sb eq & $M J$ & $\mathrm{~kg} \mathrm{C} 2 \mathrm{H} 4 \mathrm{eq}$ & kg SO2 eq & kg PO4 eq \\
\hline Market sugar beet & $5.98 \times 10^{-4}$ & 2625.05 & $5.47 \times 10^{-2}$ & 1.91 & 1.40 \\
\hline Market straw & $4.83 \times 10^{-5}$ & 68.01 & $1.59 \times 10^{-3}$ & 0.06 & 0.13 \\
\hline Market Polypropylene & $3.86 \times 10^{-7}$ & 107.49 & $6.71 \times 10^{-4}$ & 0.01 & $1.21 \times 10^{-3}$ \\
\hline Tap water & $1.14 \times 10^{-9}$ & 0.00 & $1.22 \times 10^{-7}$ & 0.00 & $1.96 \times 10^{-6}$ \\
\hline Application (sprayer) & $1.16 \times 10^{-4}$ & 168.67 & $5.32 \times 10^{-3}$ & 0.09 & 0.03 \\
\hline Tractor & $3.09 \times 10^{-6}$ & 7.18 & $2.23 \times 10^{-4}$ & 0.00 & $1.01 \times 10^{-3}$ \\
\hline Transport, passenger car & $1.41 \times 10^{-4}$ & 187.91 & $3.38 \times 10^{-3}$ & 0.04 & 0.01 \\
\hline Stretch blow moulding & $1.73 \times 10^{-6}$ & 33.51 & $7.53 \times 10^{-4}$ & 0.02 & $8.24 \times 10^{-3}$ \\
\hline Machine Steel & $6.36 \times 10^{-5}$ & 44.73 & $2.40 \times 10^{-3}$ & 0.02 & 0.01 \\
\hline Machine packaging & $1.27 \times 10^{-7}$ & 7.26 & $1.18 \times 10^{-4}$ & 0.00 & $3.93 \times 10^{-4}$ \\
\hline Machine Transport & $3.44 \times 10^{-5}$ & 133.43 & $3.57 \times 10^{-3}$ & 0.04 & 0.01 \\
\hline Machine Electricity & $1.01 \times 10^{-5}$ & 122.33 & $1.83 \times 10^{-3}$ & 0.04 & 0.03 \\
\hline Machine Cabling & $1.17 \times 10^{-3}$ & 82.93 & $7.24 \times 10^{-3}$ & 0.18 & 0.14 \\
\hline Impact category & Human toxicity & $\begin{array}{l}\text { Fresh water } \\
\text { aquatic ecotox. }\end{array}$ & $\begin{array}{l}\text { Marine aquatic } \\
\text { ecotoxicity }\end{array}$ & Terrestrial ecotoxicity & $\begin{array}{l}\text { Ozone layer depletion } \\
\text { (ODP) }\end{array}$ \\
\hline Unit & kg 1,4--DB eq & kg 1,4--DB eq & kg 1,4--DB eq & kg 1,4--DB eq & kg CFC-11 eq \\
\hline Market sugar beet & 68.13 & 42.21 & $152,690.72$ & -0.80 & $2.23 \times 10^{-5}$ \\
\hline Market straw & 5.19 & 21.55 & 4912.50 & 8.86 & $6.82 \times 10^{-7}$ \\
\hline Market Polypropylene & 0.15 & 0.08 & 287.93 & $3.58 \times 10^{-4}$ & $2.23 \times 10^{-8}$ \\
\hline Tap water & 0.00 & 0.00 & 0.71 & $4.17 \times 10^{-6}$ & $4.4 \times 10^{-11}$ \\
\hline Application (sprayer) & 7.84 & 3.30 & 8638.86 & 0.03 & $1.68 \times 10^{-6}$ \\
\hline Tractor & 0.33 & 0.18 & 1354.00 & $1.65 \times 10^{-3}$ & $6.63 \times 10^{-8}$ \\
\hline Transport, passenger car & 10.80 & 8.69 & 9875.57 & 0.02 & $2.09 \times 10^{-6}$ \\
\hline Stretch blow moulding & 1.00 & 0.99 & 3804.40 & $5.75 \times 10^{-3}$ & $2.12 \times 10^{-7}$ \\
\hline Machine Steel & 18.63 & 6.67 & $11,727.20$ & 0.09 & $2.55 \times 10^{-7}$ \\
\hline Machine packaging & 0.01 & 0.00 & 52.86 & $1.99 \times 10^{-3}$ & $4.86 \times 10^{-8}$ \\
\hline Machine Transport & 3.23 & 2.03 & 5468.53 & 0.01 & $1.49 \times 10^{-6}$ \\
\hline Machine Electricity & 1.81 & 3.41 & 5454.71 & 0.05 & $1.24 \times 10^{-6}$ \\
\hline Machine Cabling & 71.39 & 33.91 & $95,333.02$ & 0.08 & $1.82 \times 10^{-6}$ \\
\hline
\end{tabular}

Figure 5. CML midpoint indicators.

\begin{tabular}{|c|c|c|c|c|}
\hline Impact category & Unit & Wood & Machine & Organic coating beet \\
\hline Abiotic depletion & $\left(10^{-4}\right) \mathrm{kg} \mathrm{Sb} \mathrm{eq}$ & 7.27 & 12.80 & 9.08 \\
\hline Abiotic depl. (fossil) & MJ & 4.931.49 & 390.68 & $3,197.84$ \\
\hline Global warming & $\mathrm{kg} \mathrm{CO} 2 \mathrm{eq}$ & $69,690.82$ & 27.39 & 288.85 \\
\hline Ozone layer depletion & $\left(10^{-5}\right) \mathrm{kg} \mathrm{CFC-11} \mathrm{eq}$ & 4.77 & 0.49 & 2.71 \\
\hline Human toxicity & $\mathrm{kg} 1,4-\mathrm{DB}$ eq & 3.949 .86 & 95.08 & 93.44 \\
\hline Freshwater aquatic ecotox & $\mathrm{kg} \mathrm{1,4--DB} \mathrm{eq}$ & 98.16 & 46.02 & 77.01 \\
\hline Marine aquatic ecotox. & $\left(10^{5}\right) \mathrm{kg} \mathrm{1,4-DB} \mathrm{eq}$ & 1.19 & 1.18 & 1.82 \\
\hline Terrestrial ecotoxicity & $\operatorname{kg} 1,4--D B e q$ & 1.92 & 0.23 & 8.11 \\
\hline Photochemical oxidation & $\mathrm{kg} \mathrm{C} 2 \mathrm{H} 4 \mathrm{eq}$ & 5.52 & 0.02 & 0.07 \\
\hline Acidification & $\mathrm{kg} \mathrm{SO} 2 \mathrm{eq}$ & 6.42 & 0.28 & 2.13 \\
\hline Eutrophication & kgPO4-eq & 4.96 & 0.20 & 1.58 \\
\hline
\end{tabular}

Figure 6. CML indicators for the beet organic coating and the machinery compared to the wood-burning technique. 


\subsection{Sensitivity Analysis}

Regarding the method selected, the results calculated under the CML with SimaPro [44] excluded 1162 flows. Therefore, a sensitivity analysis was also performed using the ReCiPe Midpoint Europe (H) V1.11 method, reducing the excluded flows to a total of 508. ReCiPe was developed by the Dutch National Institute for Public Health and the Environment, the Radboud University, the Norwegian University of Science and Technology, and PRéConsultants, and it has 18 midpoint indicators [46,47].

In Figure 7, the results for the CML categories with correspondence in the ReCiPe method are presented. The total emissions attributed to the protection of one hectare of the vineyard are the same for climate-changing, ozone layer depletion, human toxicity, acidification, and abiotic depletion indicators. For the other categories, the impacts are higher under $\mathrm{CML}$, except for photochemical oxidation. The cabling components are responsible for most of the metal depletion, human toxicity, freshwater and marine ecotoxicities, and freshwater eutrophication in agreement with the CML method. The market for straw impacts mostly on the terrestrial eco-toxicity and water depletion indicators.



Figure 7. Sensitivity analysis with ReCiPe and CML methods.

A further simulation was performed using sugar cane as input. In Figure 8, sugar cane emissions are overall higher than sugar beet. However, for some reference indicators such as global warming, sugar cane impacts are lower.

\subsection{Cost Analysis to Produce the Organic Frosting Protection}

Table 3 is an extension of a previously published study in [19]. The table presents five different quantities of raw material considering a modification in the coating thickness and improving the insulating efficiency. Here, raw material inputs and thermal energy consumption with their corresponding costs were calculated for producing the organic coating for one hectare of vineyard. 


\begin{tabular}{|c|c|c|c|}
\hline Impact category & Unit & Organic coating beet & Organic coating sugar cane \\
\hline Abiotic depletion & $\left(10^{-4}\right) \mathrm{kg} \mathrm{Sbeq}$ & 9.08 & 13.27 \\
\hline Abiotic depl. (fossil) & $\left(10^{3}\right) M J$ & 3.20 & 2.68 \\
\hline Global warming & $\mathrm{kgCO} 2 \mathrm{eq}$ & 288.85 & 244.10 \\
\hline Ozone layer depletion & $\left(10^{-5}\right) \mathrm{kgCFC}-11 \mathrm{eq}$ & 2.71 & 2.53 \\
\hline Human toxicity & $\operatorname{kg~1,4--DB~eq}$ & 93.44 & 687.76 \\
\hline Freshwater aquatic ecotox & $k g$ 1,4--DB eq & 77.01 & 149.28 \\
\hline Marine aquatic ecotox. & $\left(10^{5}\right) \mathrm{kg} \mathrm{1,4--DB} \mathrm{eq}$ & 1.82 & 1.66 \\
\hline Terrestrial ecotoxicity & $k g$ 1,4--DB eq & 8.11 & 13.09 \\
\hline Photochemical oxidation & $\mathrm{kg} \mathrm{C} 2 \mathrm{H} 4 \mathrm{eq}$ & 0.07 & 2.75 \\
\hline Acidification & $\mathrm{kg} \mathrm{SO} 2 \mathrm{eq}$ & 2.13 & 2.85 \\
\hline Eutrophication & $\mathrm{kg} P O 4 \mathrm{eq}$ & 1.58 & 1.75 \\
\hline
\end{tabular}

Figure 8. CML-IA indicators for the Organic coating from beet and cane.

Table 3. Cost related to sucrose and thermal energy spent to cover one hectare of vineyard surface wire.

\begin{tabular}{ccccc}
\hline \multicolumn{4}{c}{ Tests Carried out with Sucrose and Straw } & \\
\hline Sugar Used in 1 He [kg] & Cost of Raw Materials [€] & Thermal Energy [kWh] & $\begin{array}{c}\text { Cost of Energy } \\
\text { Consumption [€] }\end{array}$ & Overall Costs [€] \\
\hline 250 & 237 & 4612.5 & 960 & 1200 \\
500 & 474.75 & 3787.5 & 787.5 & 1260 \\
749 & 711.75 & 3577.5 & 742.5 & 1455 \\
999 & 948.75 & 3255 & 675 & 1627.5 \\
1249 & 1186.5 & 2925 & 607.5 & 1792.5 \\
\hline
\end{tabular}

\section{Discussion}

\subsection{Environmental Impact Aspects}

According to the calculations, the traditional technique substitution could represent an equivalent of $69,375 \mathrm{~kg} \mathrm{CO}$ eq in emissions savings in each organic coating application. Another important aspect of the designed model is that the straw employed was not considered a waste product from another system, and therefore its impact was considered particularly important regarding freshwater and terrestrial eco-toxicity. Once the straw is considered as waste, all impacts attributed to its production are associated with another system and excluded from this one. The LCA of the organic coating revealed that the sugar beet and the metallic parts of the machine are also system hotspots.

Since sugar is the main component responsible for the system's impacts, a new system using sugar cane was calculated to determine whether there would be a difference in the impact. The sugar beet is mostly produced in Europe [48], the geography of this study. Therefore, one could think that it would present a better environmental performance as less transportation is required. However, the scale of production, the type of energy employed, different transportation means, among other variables, might have led us to non-obvious results in abiotic depletion, global warming potential, ozone layer depletion, and marine aquatic ecotoxicity indicators, setting a point to deepen the study.

It is important to highlight that our study is a projection of a laboratory experiment that was extrapolated to an operation scale. Our model considered that one application is enough to protect one hectare of a vineyard. However, wind and humidity conditions might demand more applications. This work also did not measure the disadvantages of 
the traditional wood-burning $[23,25,27]$ system that can potentially damage the vineyards with fire accidents, requiring a constant follow-up. The odor and direct damage to the workers were also not considered.

\subsection{Cost Aspects}

Costs are a determinant for designing a protection strategy for a vineyard [21-23,27]. E. B. Poling [22] proposes a diagram to assist with the event diagnosis that should match a management solution. However, some strategies are associated with high initial costs as, for example, the fans mentioned in the Introduction section, therefore not viable for many producers.

The potential cost analysis associated with the strategy proposed in this work and already described in previous research $[18,19]$ is discussed here.

As the tests were carried out by a small-scale approach, the costs of the novel technique cannot be considered completely adherent to future practical application. However, results achieved in this work and previous ones allowed us to define with accuracy the raw materials and thermal energy required to ensure complete protection of vineyards from late frosts. Therefore, it is possible to compare the initial input costs associated with the conventional and the prospective novel technique, not operational practices.

The adoption of greater amounts of raw materials led to a drastic reduction of thermal energy needed to maintain temperature constantly above the ice point. However, in their work [19], Di Giuseppe et al. proved that in some cases, a lower quantity of raw materials may be enough to successfully address the late frost.

The cost evaluation excluded the straw since it was obtained as waste with commonly large availability in the surroundings of the chosen geography. In this case, the costs associated with its production, purchase, and transport were considered negligible.

According to experts and specialized magazines [25,28], one hectare of vineyard requires from 200 to 400 fire spots, according to the cultivation density. In Umbria, at present, the raw wood cost is estimated at $10 € / 100 \mathrm{~kg}$ varying with the quantity negotiated, type of wood, and market demand. Considering an average consumption of $80 \mathrm{~kg}$ for each fire spot, it could lead to a cost of $3200 € /$ hectare for one single frost event, excluding other operation costs.

Alternatively, fuel burners with a cost of about $9 €$ per unit can be estimated at $3600 € /$ hectare. The slightly higher cost can be compensated by easier raw material transportation and the lower controlling requirements during the operation. Another equivalent method [25], with portable ovens, costs $€ 300$ per unit and requires about 30 units for a hectare with the advantages of not producing smoke and can be placed in riskier areas. Bougie candles, according to Alistair Nesbitt [28], can be estimated at $£ 2400$ per hectare, with raw materials costs of $£ 8$ to $£ 10$.

The novel technique scaled presented costs about $€ 1800$, in the higher mass case, which seems to be feasible for implementation, i.e., less expensive than the other technique simulated, considering the raw material inputs.

As explained before, this technique has been exclusively theoretically proposed, and only a few laboratory-scale experiments were carried out; for that reason, costs associated with instruments and maintenance are not currently available.

\section{Conclusions}

In the last decades, given the ongoing climate change and overall impacts also attributed to agricultural practices, many efforts are being made to identify innovative, sustainable, and economic techniques to be used in the sector.

The work presented an investigation of the potential environmental impacts of an experimental organic coating against late frost events. This is a protection process that is often not reported in the vineyard life cycle assessment studies. We aim to use the findings of this research to reduce the technique impacts once on an operational scale. As academics, we also aim to contribute to the usage of the LCA methodology for techniques 
under development in their early stages. The method demonstrated advantages under the ecological aspect in comparison to common practices (200 times less for global warming indicator) and also regarding the safety of the organic frosting protection.

A preliminary cost analysis for one hectare of the vineyard was carried out revealing the potentialities of using sugar-coating and straw to create the organic frosting protection. The cost assessment demonstrated a reduction of about $10 \%$ in costs with the thicker sugar layer in comparison to the wood-burning simple costs. If the thinner sugar layer is considered, it represents only $45 \%$ of the costs of simple oak burning. Since this technique has been exclusively theoretically proposed, this analysis considers the costs of raw material needed and thermal energy consumption employed at the lab scale.

Further research should consist of applying the insulating coating in vineyards as well as examining the type of sugar employed. Moreover, more detailing of the organic coating in practice needs to be detailed, including methods for distributing the sugar-coating and its durability.

Author Contributions: F.R., A.N., and A.L.P. conceived and designed the research, F.F.d.A.L., A.D.G., and A.M.G. drafted the manuscript and prepared figures. A.P., A.L.P., and A.N. revised the manuscript. All authors have read and agreed to the published version of the manuscript.

Funding: This research received no external funding.

Institutional Review Board Statement: Not applicable.

Informed Consent Statement: Not applicable.

Data Availability Statement: Not applicable.

Acknowledgments: The authors Fabiana Frota de Albuquerque Landi's and Alessia Di Giuseppe's acknowledgments are due to the PhD school in Energy and Sustainable Development from the University of Perugia.

Conflicts of Interest: The authors declare no conflict of interest.

\section{References}

1. Coltivazioni: Uva, Vino, Olive, Olio. Available online: http://www.istat.it (accessed on 17 December 2020).

2. Osservatori RRN. Indicatori Di Competitività-Agroalimentare-Produzione Agricola Per Settore a Valori Correnti. Osservatori RRN-Ismea. Available online: http://www.ismeamercati.it/osservatori-rrn/indicatori-competitivita/agroalimentare/ produzione-agricola-per-settore-valori-correnti (accessed on 17 December 2020).

3. Scheda Di Settore-Vino. Available online: http://www.ismeamercati.it/report-analisi-agroalimentare/schede-settore (accessed on 18 December 2020).

4. Focus Uve da Tavola. Available online: www.ismeamercati.it (accessed on 18 December 2020).

5. Vermeulen, S.J.; Campbell, B.M.; Ingram, J.S.I. Climate change and food systems. Annu. Rev. Environ. Resour. 2012, 37, 195-222. [CrossRef]

6. Smith, P.; Martino, D.; Cai, Z. Agriculture. In Climate change 2007: Mitigation. Contribution of Workgroup III to the Fourth Assessment Report of the Intergovernamental Panel on Climate Change; Metz, B., Davidson, O.R., Bosch, P.R., Dave, R., Meyer, L.A., Eds.; Cambridge University Press: New York, NY, USA, 2007.

7. UN Food and Agricultural Organization. Livestock's Long Shadow: Environmental Issues and Options; UN Food and Agriculture Organization: Rome, Italy, 2006.

8. Bock, A.; Sparks, T.; Estrella, N.; Menzel, A. Changes in the phenology and composition of wine from Franconia, Germany. Clim. Res. 2011, 50, 69-81. [CrossRef]

9. IPPC. Summary for Policymakers. Climate Changes 2013. The Physical Science Basis. Contribution of Working Group I to the Fifth Assessment Report on the Intergovernmental Panel on Climate Change; Cambridge University Press: Cambridge, UK, 2013.

10. Duchêne, E.; Huard, F.; Dumas, V.; Shneider, C.; Merdinoglu, D. The challenge of adapting grapevine varieties to climate change. Clim. Res. 2010, 41, 193-204. [CrossRef]

11. Leolini, L.; Moriondo, M.; Fila, G.; Costafreda-Aumedes, S.; Ferrise, R.; Bindi, M. Late spring frost impacts on future grapevine distribution in Europe. Field Crops Res. 2018, 222, 197-208. [CrossRef]

12. Cuccia, C.; Bois, B.; Richard, Y.; Parker, A.K.; de Cortazar-Atauri, I.G.; van Leeuwen, C.; Castel, T. Phenological model performance to warmer conditions: Application to Pinot Noir in Burgundy. J. Int. Sci. Vigne. Vin. 2014, 48, 169-178. [CrossRef]

13. de Orduña, R.M. Climate change associated effects on grape and wine quality and production. Food Res. Int. 2010, 43, 1844-1855. [CrossRef] 
14. Jones, G.V.; White, M.A.; Cooper, O.R.; Storchmann, K. Climate change and global wine quality. Clim. Chang. 2005, 73, 319-343. [CrossRef]

15. Marta, A.D.; Grifoni, D.; Mancini, M.; Storchi, P.; Zipoli, G.; Orlandini, S. Analysis of the relationships between climate variability and grapevine phenology in the Nobile di Montepulciano wine production area. J. Agric. Sci. 2010, 148, 657-666. [CrossRef]

16. Molitor, D.; Caffarra, A.; Sinigoj, P.; Pertot, I.; Hoffmann, L.; Junk, J. Late frost damage risk for viticulture under future climate conditions: A case study for the Luxembourgish winegrowing region. Aust. J. Grape Wine Res. 2014, 20, 160-168. [CrossRef]

17. Orlandini, S.; di Stefano, V.; Lucchesini, P.; Puglisi, A.; Bartololini, G. Current trends of agroclimatic indices applied to grapevine in Tuscany (Central Italy). Q. J. Hung. Metereol. Serv. 2009, 113, 69-78.

18. di Giuseppe, A.; Gambelli, A.M.; Rossi, F.; Nicolini, A.; Ceccarelli, N.; Palliotti, A. Insulating Organic Material as a Protection System against Late Frost Damages on the Vine Shoots. Sustainability 2020, 12, 6279. [CrossRef]

19. di Giuseppe, A.; Gambelli, A.M.; Rossi, F.; Nicolini, A.; Ceccarelli, N.; Palliotti, A. A natural organic coating to control and minimize late frost damages on wine shoots. Heat Transf. Res. 2020, 51, 1625-1635. [CrossRef]

20. Evans, R.G. The Art of Protecting Grapevines from Low Temperature Injury. In Proceedings of the ASEV 50th Anniversary Meeting, Seattle, WA, USA, 19-23 June 2000; pp. 60-72.

21. Miranda, C.; Bilavcik, A.; Chaloupka, R.; Dreisiebner, S. EIP-AGRI Focus Group Protecting fruit production from frost damage. EIP-AGRI Agric. Innov. 2019, 20, 809-912.

22. Poling, E.B. Spring cold injury to winegrapes and protection strategies and methods. HortScience 2008, 43, 1652-1662. [CrossRef]

23. Evans, R.G. The ABCs of frost management. In Proceedings of the 104th Annual Meeting of the Washington State Horticultural Association, Yakima, WA, USA, 1-3 December 2009; pp. 79-96.

24. Bonciarelli, F.; Bonciarelli, U. Agronomia, 1st ed.; RCS Scuola S.p.A.: Milano, Italy, 2003; pp. 32-35.

25. Giving Frost the Cold Shoulder. Available online: https://www.vineyardmagazine.co.uk/giving-frost-the-cold-shoulder/ (accessed on 2 February 2021).

26. Zinoni, F.; Antolini, G.; Palara, U.; Rossi, F.; Reggidori, G. Aspetti fisici ed ecofisiologici nella previsione e difesa delle piante da frutto dalle gelate tardive. Italus Hortus 2005, 12, 63-78.

27. Snyder, R.L.; de Melo-Abreu, J.P. Frost protection: Fundamentals, practice and economics. In Environment and Natural Resources Series 10; FAO: Rome, Italy, 2005.

28. Nesbitt, A. Are You looking for an Alternative to Bougies? Available online: https://www.vinescapes.com/vineyardestablishment/are-you-looking-for-an-alternative-to-bougies/ (accessed on 2 February 2021).

29. Napa County California Valuing Wind Machines. Available online: https://www.countyofnapa.org/1073/Valuing-WindMachines (accessed on 5 February 2021).

30. Hannan, J. Frost Protection for High Density Orchards. Available online: https://www.extension.iastate.edu/smallfarms / frostprotection-high-density-orchards (accessed on 2 February 2021).

31. Lockshin, L.; Corsi, A.M. Consumer behaviour for wine 2.0: A review since 2003 and future directions. Wine Econ. Policy 2012, 1, 2-23. [CrossRef]

32. Bartocci, P.; Fantozzi, P.; Fantozzi, F. Environmental impact of Sagrantino and Grechetto grapes cultivation for wine and vinegar production in central Italy. J. Clean. Prod. 2017, 140, 569-580. [CrossRef]

33. Neto, B.; Dias, A.C.; Machado, M. Life cycle assessment of the supply chain of a Portuguese wine: From viticulture to distribution. Int. J. Life Cycle Assess. 2013, 18, 590-602. [CrossRef]

34. Bosco, S.; di Bene, C.; Galli, M.; Remorini, D.; Massai, R.; Bonari, E. Greenhouse Gas Emissions in the Agricultural Phase of Wine Production in the Maremma Rural District in Tuscany, Italy. Ital. J. Agron. 2011, 6, 93-100. [CrossRef]

35. Barry, M.T. Life Cycle Assessment and the New Zealand Wine Industry: A Tool to Support Continuous Environmental Improvement. Master's Thesis, Massey University, Wellington, New Zealand, 2011.

36. European Commission. ILCD Handbook-General Guide on LCA-Detailed Guidance; European Commission, Publications Office of the European Union: Luxembourg, 2010; ISBN 9789279190926.

37. International Organization for Standardization. ISO 14040:2006 Environmental Management_Life Cycle Assessment_Principles and Framework; ISO: Geneva, Switzerland, 2006.

38. International Organization for Standardization. ISO 14040:2006 Environmental Management_Life Cycle Assessment—Requirements and Guidelines; ISO: Geneva, Switzerland, 2006.

39. Zampori, L.; Saouter, E.; Castellani, V.; Schau, E.; Cristobal, J.; Sala, S. Guide for Interpreting Life Cycle Assessment Result; Publications Office of the European Union: Luxembourg, 2016. [CrossRef]

40. Cavazza, D. Nuova Enciclopedia Agraria Italiana. Parte V; Viticoltura; UTET: Turin, Italy, 1914; pp. $473-475$.

41. ISTAT. Temperatura e Precipitazione nelle Principali Città. Anni 2002-2016. Available online: https://www.istat.it/it/files//201 8/06/Report_Meteoclima.pdf (accessed on 18 December 2020).

42. Werner, F.; Hischier, R. Aktualisierung der Modelle und Datensätze zu Holz und Holzprodukten in der Datenbank ecoinvent, Schlussbericht. Available online: https://www.bafu.admin.ch/bafu/de/home/themen/wald/fachinformationen/strategienund-massnahmen-des-bundes/aktionsplan-holz/projektuebersicht-und-ergebnisse-des-aktionsplans-holz0/ergebnisse-datengrundlagen-.html (accessed on 20 December 2020).

43. Wernet, G.; Bauer, C.; Steubing, B.; Reinhard, J.; Moreno-Ruiz, E.; Weidema, B. The ecoinvent database version 3 (part I): Overview and methodology. Int. J. Life Cycle Assess. 2016, 21, 1218-1230. [CrossRef] 
44. PRé Sustainability B.V. SimaPro 8.4.0.0. Available online: https://simapro.com/2017/new-in-simapro-8-4/ (accessed on 5 July 2017).

45. Doka, G. Treatment of Waste Wood, Untreated, Municipal Incineration. Ecoinvent Database, GLO 2020. Available online: https://www.ecoinvent.org/files/change_report_v3_5_20180823.pdf (accessed on 1 May 2021).

46. PRé Sustainability B.V. Simapro Database Manual. Available online: https://support.simapro.com/articles/Manual/SimaProMethods-manual (accessed on 1 May 2021).

47. Huijbregts, M.A.J.; Steinmann, Z.J.N.; Elshout, P.M.F.; Stam, G.; Verones, F.; Vieira, M.; Zijp, M.; Hollander, A.; van Zelm, R. ReCiPe2016: A harmonised life cycle impact assessment method at midpoint and endpoint level. Int. J. Life Cycle Assess. 2017, 22, 138-147. [CrossRef]

48. European Commission Joint Research Center. Environmental Factsheet: Sugar. Available online: https://ec.europa.eu/jrc/sites/ jrcsh/files/QMS_H08_BISO_D.8_BISO-EnvSust-Food-and-feed-Sugar_150513.pdf (accessed on 5 January 2021). 